\title{
In Vitro and In Vivo Test of Boron Delivery Agent for Boron Neutron Capture Therapy
}

\author{
Sista Dyah Wijaya ${ }^{1 *}$, Bagaswoto Poedjomartono ${ }^{2}$ and Yohannes Sardjono ${ }^{3}$ \\ ${ }^{I}$ Pharmaceutical Science and Technology, School of Pharmacy, Bandung Institute of Technology \\ ${ }^{2}$ Department of Radiology, Radionuclear Services, Faculty of Medicine, Public Health, and Nursing, Universitas Gadjah Mada \\ ${ }^{3}$ Centre for Accelerator and Science Technology, National Nuclear Energy Agency Indonesia
}

\begin{tabular}{l} 
ARTICLE INFO \\
\hline Article history: \\
Received: 14 August 2018 \\
Received in revised form: 1 June 2019 \\
Accepted: 30 June 2019 \\
\hline Keywords: \\
In vivo \\
In vitro \\
Boron delivery agent \\
BNCT \\
clinical studies
\end{tabular}

\begin{abstract}
A B S T R A C T
BNCT is an alternative therapy for treating cancer. The principle of BNCT involves a neutron boron capture and a nuclear reaction that produce alpha particle and $\mathrm{Li}$ ion with a high level of linear energy transfer in the tissue. It is effective in killing tumor cells. To administer boron in the tumor cells, a boron delivery agent is needed. Thus far, there are a variety of boron delivery agents that have been developed. To date, just two main boron-based drugs, BPA and BSH, have been used for clinical studies. Many other boron delivery agents have been evaluated in vivo and in vitro but have not been evaluated clinically. Therefore, the other boron delivery agents have not been used in BNCT clinical studies.
\end{abstract}

\section{INTRODUCTION}

Cancer is a disease which abnormal cells grow out of control and affect different organs. Cancer can spread to any organs. In 2018, there were 9.6 million deaths in the world caused by cancer. The most common organs that are infected by cancer are the lungs, breasts, colon, prostate, skin, and stomach. The types of cancer treatments that exist are surgery, chemotherapy, radiotherapy, hormone therapy, targeted therapy, and immunotherapy. For some people, there are many side effects after receiving a treatment for cancer including nausea and fatigue [1.2]. To minimize side effects from the treatment of cancer, researchers have been considering called an alternative of therapy cancer that can selectively destroy cancer cells and spare normal cells [3].

Boron neutron capture therapy (BNCT) is a binary therapy for healing cancer [4]. The principle mechanisms of BNCT are nuclear uptake and fission reaction. In BNCT, boron $\left({ }_{5}^{10} \mathrm{~B}\right)$ that accumulated in a tumor cell by applying a specific carrier is irradiated by low thermal energy-neutrons. The captured neutron in boron produces alpha particle and ${ }_{3}^{7} \mathrm{Li}$ ions $\left({ }_{5}^{10} \mathrm{~B}(\mathrm{n}, \alpha){ }_{3}^{7} \mathrm{Li}\right)$ (Fig.1) with a high level of linear energy transfer at tissue. So, it could be effective in killing tumor cells (Fig.2) [5]. Component BNCT that delivers boron selectively to the tumor cells is boron delivery agent. This agent must deliv'er enough of ${ }_{5}^{10} \mathrm{~B}$ to the tumor cell to sustain $\left({ }_{5}^{10} \mathrm{~B}(\mathrm{n}, \alpha){ }_{3}^{7} \mathrm{Li}\right)$ capture reaction in order to damage tumor cell

\footnotetext{
1* Corresponding author. E-mail address: sistawijaya@students.itb.ac.id
} 
efficiently. Moreover, boron must stay in tumor cells for a length of time and stay clear from the surrounding normal cells. Ideally, the tumor to normal cell ratio is greater than 3-4:1 [6]. In clinical studies of BNCT, the two main boronsbased drugs are sodium mercaptoundecahyhdrododecarbonate

$\left(\mathrm{Na}_{2}{ }^{10} \mathrm{~B}_{12} \mathrm{H}_{11} \mathrm{SH} ; \quad \mathrm{Na}_{2}{ }^{10} \mathrm{BSH}\right)$ and $\mathrm{L}-p$ boronophenylalanine (L- $\left.{ }^{10} \mathrm{BPA}\right)$ used for the treatment of malignant brain tumors and malignant melanoma [5]. BNCT has been focused on the treatment of malignant gliomas and until recently, head and neck and liver cancers. [13].

$$
\begin{aligned}
& { }^{4} \mathrm{He}+{ }^{7} \mathrm{Li}+2.79 \mathrm{MeV}(6 \%) \\
& \uparrow \\
& { }^{10} B+n_{\text {th }}(0.025 \mathrm{eV}) \rightarrow\left[{ }^{11} \mathrm{~B}\right] \\
& { }^{4} \mathrm{He}+{ }^{7} \mathrm{Li}+2.31 \mathrm{MeV} \text { (94\%) } \\
& \downarrow \\
& { }^{7} \mathrm{Li}+\gamma+0.48 \mathrm{MeV}
\end{aligned}
$$

Fig 1. Nuclear reaction occurs in boron of BNCT [9]

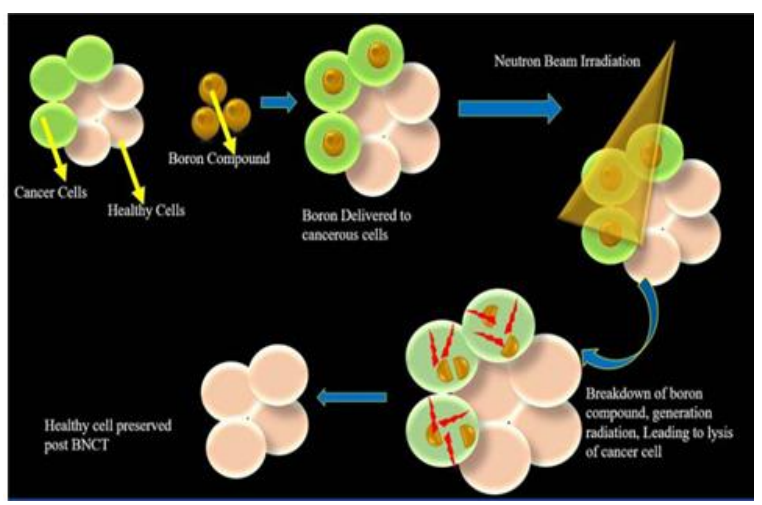

Figure 2. Scheme application of BNCT in tumor cell [10]

\section{MATERIALS AND METHODS}

\subsection{Boron Delivery Agent}

The important requirements for a boron delivery agent in BNCT include the following: 1) concentration of boron in the tumor cell in the range of 20-35 $\mu \mathrm{g}$ per gram of the tumor cell and the ability to clear from the blood and normal cells relatively quickly, 2) low toxicity, and 3) selective to the tumor cell, can destroy only the tumor cells without affecting the healthy cells
[7]. Based on previous study, development of a boron delivery agent taken three generations.

\section{First generation boron delivery agent}

In the 1950s and early 1960s, boric acid and its derivatives as delivery agents were first used in clinical trials. Currently, Boronophenylanine (BPA) and (Polyhedral mercaptoborone) $\mathrm{BSH}$ are in Phase I and Phase II clinical trials, and both have a long history of preclinical studies. A third derivative is GB-10 that is currently being approved by the FDA [11.5]. These first generation of BPA and $\mathrm{BSH}$, however, were to be poor at tumor retention, non-selective, toxic, and poor at penetrating tumor.

\section{Second generation boron delivery agent}

In 1960's, the second generation of boron delivery agents BPA and BSH entered the clinical trials. They had low toxicity, longer retention of tumor cells, and a ratio of tumor: normal cell greater than 1 [10]. BPA is a boron compound containing neutral amino acid phenylalanine. BPA's structure is analogous to tyrosine as a precursor for synthesizing the pigment melanin. It was tested as a boron delivery agent of BNCT for malignant melanoma. Based on in vitro and in vivo test, BPA accumulated selectively in B16 melanoma cells [11]. Furthermore, BPA has more therapeutic effect than BSH based on clinical trials in the US, Finland, Sweden and Japan [6]. BPA is utilized for experimental study on brain tumor therapy. According to Coderre et al. 's study, BPA is transported into rat gliosarcoma cells by a L-amino acids transporter system [2]. L-amino acids transporter system is highly expressed in brain tumor cells than in normal cells [14]. BPA has been mixed with fructose (L-BPA-F) in order to obtain high solubility in water and is improved with 10B [8].

BSH molecule that localize selectively in brain tumors and penetrates the disrupted blood brain barrier by passive diffusion. BSH couldn't cross the intact BBB [8]. BSH doesn't have specific transporter to the tumor, but BSH per molecule could carry molecule ${ }_{5}^{10} B \quad 12$ times more than BPA [14]. In vitro, BSH accumulated in the cytoplasm and the nucleus of cells [11]. Otersen et al explains BSH has a negative charge by quaternary ammonium salts that can 
bind to the positive charge of choline residues on phospholipids, which occur in membrane that contains phosphatidylcholine and spignomyeline. Choline is more highly expressed in tumor cells than in the white matter of normal cells [15].

\section{Third generation boron delivery agent}

A new number of boron delivery agents have been developed recently in order to deliver boron selectively to the target and to obtain a therapeutic concentration of boron [6]. Third generation boron delivery agents have better stability and selectivity than previous generations. The strategy to develop a boron delivery agent is incorporate it with a compound that has selectivity and specificity to the target such as peptides, proteins, antibodies, nucleosides, sugars, porphyrins, liposomes and nanoparticles [16].

\section{RESULTS AND DISCUSSION}

These are some of boron delivery agents with their current status.

Table 1. Summary of new boron delivery agents

\begin{tabular}{|c|c|c|}
\hline $\begin{array}{l}\text { Boron } \\
\text { Delivery } \\
\text { Agent }\end{array}$ & $\begin{array}{l}\text { Mechanism of } \\
\text { Localization }\end{array}$ & $\begin{array}{l}\text { Current } \\
\text { status }\end{array}$ \\
\hline $\mathrm{BPA}$ & $\begin{array}{l}\text { Uptake by L-type } \\
\text { amino acid transporters } \\
\text { and cell membrane } \\
\text { diffusion }[20] .\end{array}$ & $\begin{array}{l}\text { Clinical } \\
\text { studies } \\
{[17]}\end{array}$ \\
\hline $\mathrm{BSH}$ & $\begin{array}{l}\text { Accumulate in tumor } \\
\text { cells by passive } \\
\text { transport with the } \\
\text { destruction of the blood } \\
\text { brain barrier (BBB) } \\
{[30] \text {. }}\end{array}$ & $\begin{array}{l}\text { Clinical } \\
\text { studies } \\
{[17]}\end{array}$ \\
\hline $\begin{array}{l}\text { Nucleoside } \\
\text { and } \\
\text { Carbohydrate } \\
\text { Analog }\end{array}$ & $\begin{array}{l}\text { Localize in tumor cells } \\
\text { by kinase mediated } \\
\text { trapping [24]. } \\
\text { Thymidine kinase } \\
\text { (TK1) is highly } \\
\text { expressed in a tumor } \\
\text { cell that is actively } \\
\text { proliferating [22, 23]. }\end{array}$ & $\begin{array}{l}\text { Preclinical } \\
\text { studies [22, } \\
23]\end{array}$ \\
\hline $\begin{array}{l}\text { Unnatural } \\
\text { Amino Acids } \\
(\mathrm{ABCPC} \text { and } \\
\text { ACBC) }\end{array}$ & $\begin{array}{l}\text { Uptake by } \begin{array}{r}\text { L-type } \\
\text { amino }\end{array} \\
\text { transporters acids } \\
\text { phenylalanine } \\
{[14] .}\end{array}$ & $\begin{array}{l}\text { Preclinical } \\
\text { studies } \\
{[14]}\end{array}$ \\
\hline $\begin{array}{l}\text { Cationic } \\
\text { Polymers }\end{array}$ & $\begin{array}{l}\text { Cationic polymer } \\
\text { attracts to the anionic } \\
\text { charge around the } \\
\text { tumor cell that is }\end{array}$ & $\begin{array}{l}\text { Preclinical } \\
\text { studies } \\
{[27] .}\end{array}$ \\
\hline
\end{tabular}

\begin{tabular}{|c|c|c|}
\hline & $\begin{array}{l}\text { expressed in sialic acid } \\
\text { [27]. }\end{array}$ & \\
\hline $\begin{array}{l}\text { Porphyrin } \\
\text { Derivatives }\end{array}$ & $\begin{array}{l}\text { Accumulates in tumor } \\
\text { cells via endosomal } \\
\text { distribution and leaky } \\
\text { vasculature [17]. }\end{array}$ & $\begin{array}{l}\text { Preclinical } \\
\text { studies } \\
{[21]}\end{array}$ \\
\hline Liposome & $\begin{array}{l}\text { Localizes in tumor cells } \\
\text { via EPR effect [28]. } \\
\text { Cationic liposomes } \\
\text { attract the negative } \\
\text { charge of the outer layer } \\
\text { of mammalian plasma } \\
\text { membranes by } \\
\text { electrostatic } \\
\text { interactions [29]. }\end{array}$ & $\begin{array}{l}\text { Preclinical } \\
\text { studies } \\
{[28]}\end{array}$ \\
\hline Nanoparticles & $\begin{array}{l}\text { Accumulate in tumor } \\
\text { cells by their EPR } \\
\text { (Enhanced } \\
\text { Permeability and } \\
\text { Retention) effect [31]. }\end{array}$ & $\begin{array}{l}\text { Preclinical } \\
\text { studies } \\
{[31] .}\end{array}$ \\
\hline $\begin{array}{l}\text { Monoclonal } \\
\text { antibody }\end{array}$ & $\begin{array}{l}\text { Monoclonal antibody, } \\
\text { like cetuximab, is } \\
\text { attractive to and binds } \\
\text { with EGF receptors or } \\
\text { EGFRvIII, which are } \\
\text { overexpressed in } \\
\text { human glioblastomas } \\
\text { [26]. }\end{array}$ & $\begin{array}{l}\text { Preclinical } \\
\text { studies }[25, \\
26]\end{array}$ \\
\hline $\begin{array}{l}\text { Cell } \\
\text { Penetrating } \\
\text { Peptides }\end{array}$ & $\begin{array}{l}\text { Localize in tumor cells } \\
\text { via electrostatic } \\
\text { interaction with plasma } \\
\text { membrane and } \\
\text { penetrating a by } \\
\text { micropinocytosis [32]. }\end{array}$ & $\begin{array}{l}\text { Preclinical } \\
\text { studies } \\
{[33] .}\end{array}$ \\
\hline
\end{tabular}

In Indonesia, the development of new boron delivery agents for BNCT focuses on healing common cancers such as ovarian, cervical, breast, thyroid, skin, and soft tissue cancers. [34]. The faculty of Pharmacy Universitas Gadjah Mada have been developing a new boron delivery agent, pentagamaboronon- 0 (PGB-0) which is curcumin analogous to that used for the treatment of breast cancer with positive HER2 [35]. The current status of PGB0 is in preclinical studies and is expected going to clinical studies soon [36].

A number of clinical studies of new boron delivery agents for different varieties of tumor were reported in Europe, Asia and in the US in first decade of the 2000s [3]. Until now, there is no new boron delivery agents have progressed to clinical trials besides BPA and BSH [17]. They are stuck in in vitro and in vivo studies using animals. The reason is the lack of 
promising in vitro and in vivo tests does not encourage the success of expensive clinical biodistribution studies in humans and even indicates that such studies could be harmful for the participating. There are many steps that are feasible in pre-clinical study but very difficult to implement in clinical studies [18].

Usually, evaluation reports of boron delivery agents are related to cytotoxicity, boron delivery agent uptake in vitro by model cell lines, time course biodistribution and analysis of boron in the tumor and in the blood for systemic toxicity. Biological study for every boron delivery agent is different depending on its synthesis and chemical characteristics. More data from biological studies is important for further development of boron delivery agents [19]. In BNCT, there is no specific standard protocol either in vitro/in vivo tests and clinical studies for dose treatment planning calculation and irradiation method. Every different research center has its own method [16]. The variety of evaluation data for boron delivery agents from different research centers causes difficulty when comparing evaluation data from center to center and also makes it difficult to go to the next evaluation step with a greater population of patients in clinical studies $[19,16]$. Clinical studies development of new boron delivery agents is slow also because of the absence of a readily available proper neutron source and the high cost [21].

Strategies to improve the number of new boron delivery agents through in vitro and in vivo tests rather clinical studies include the following: 1) establish centralized facility of biological evaluation for boron delivery agents including in vitro/in vivo tests and clinical studies which have proper laboratory facilities and instruments as well as a thermal and epithermal neutron source for irradiation experiment. The facility should also be staffed with personnel who are professionals in the biological aspect of BNCT. The centralization of biological work would provide better biological standards and more well-maintained cell and neutron sources to accumulate a more comprehensive database. 2) Encourage collaborative efforts between research centers to compare and determine standard dose prescriptions for further studies on greater populations or for randomized clinical trials. 3) Standard evaluation protocols for boron delivery agents must be adaptable to evaluate a variety of new boron delivery agents and new clinical objectives $[19,16,9,11]$.

\section{CONCLUSION AND REMARKS}

BNCT is a potential treatment for healing cancer. In BNCT, a boron delivery agent is an important component to deliver boron to the tumor target. A number of boron delivery agents have been developed. But, to date, just two boron delivery agents are used in clinical studies, BSH and BPA. Therefore, some effort is required to improve the number of new boron delivery agents that could go through in vitro/in vivo test to clinical studies. So, BNCT could be used widely for cancer therapy.

\section{ACKNOWLEDGMENT}

The authors would like to thank to PSTABATAN for the opportunity to work on this research.

\section{REFERENCES}

Jacob, M., Varghese, J., Murray, R. K., \& Weil, P. A. (2015). Cancer: An Overview. Harper's Illustrated Biochemistry, 30e, 1-3. Retrieved from

http://mhmedical.com/content.aspx ?aid=11060 61033

Credits, R. (2018). Cancer 12. Cancer, (September 2018), 2018. https://doi.org/10.1016/S2214109X(16)30143-7.4

Takagaki, M., Sakai, R., Tanaka, T., Ohsawa, N., Akagi, H., \& Ono, K. (2004). Boron neutron capture therapy for malignant brain tumors. KURRI Progress Report, 140. https://doi.org/10.2176/nmc.ra.2015-0297

Coderre, J. A., \& Morris, G. M. (2006). The Radiation Biology of Boron Neutron Capture Therapy. Radiation Research, 151(1), 1. https://doi.org/10.2307/3579742

Practice, T. (2016). Boron Neutron Capture Therapy : Delivery Agents Used in, $X X(1), 25$ 32.

Barth, R. F., Mi, P., \& Yang, W. (2018). Boron delivery agents for neutron capture therapy of cancer. Cancer Communications, 38(1), 1-15. https://doi.org/10.1186/s40880-018-0299-7

Sivaev, I. B., \& Bregadze, V. V. (2009). Polyhedral boranes for medical applications: Current status and perspectives. European Journal of 
Inorganic Chemistry, (11), 1433-1450. https://doi.org/10.1002/ejic.200900003

Sauerwein, W. A. G., Wittig, A., Moss, R., \& Nakagawa, Y. (2012). Neutron capture therapy: Principles and applications. Neutron Capture Therapy: Principles and Applications, 9783642313, $1-553$. https://doi.org/10.1007/978-3-642-31334-9

R.F., B., \& A.H., S. (1997). Boron neutron capture therapy of brain tumors - Current status and future prospects. Journal of Neuro-Oncology, 33(1-2), 3-7. Retrieved from http://www.embase.com/search/results?subacti on=viewrecord \&from=export\&id=L27183 200

Nedunchezhian, K., Aswath, N., Thiruppathy, M., \& Thirugnanamurthy, S. (2016). Boron neutron capture therapy - a literature review. Journal of Clinical and Diagnostic Research, 10(12), ZE01-ZE04.

https://doi.org/10.7860/JCDR/2016/19890.902 4

Coderre, J. A., Turcotte, J. C., Riley, K. J., Binns, P. J., Harling, O. K., \& Kiger, W. S. (2003). Boron Neutron Capture Therapy: Cellular Targeting of High Linear Energy Transfer Radiation. Technology in Cancer Research and Treatment, 2(5), $355-375$. https://doi.org/10.1177/153303460300200502

Wittig, A., Sauerwein, W. A., \& Coderre, J. A. (2000). Mechanisms of transport of p-boronophenylalanine through the cell membrane in vitro. Radiation Research, 153(2), 173-180. Retrieved from http://www.ncbi.nlm.nih.gov/pubmed/1062961 6

Liao, A. H., Chou, F. I., Kuo, Y. C., Chen, H. W., Kai, J. J., Chang, C. W., ... Hwang, J. J. (2010). Biodistribution of phenylboric acid derivative entrapped lipiodol and 4-borono-2-18F-fluoro1-phenylalanine-fructose in GP7TB liver tumor bearing rats for BNCT. Applied Radiation and Isotopes, $\quad 68(3)$, 422-426. https://doi.org/10.1016/j.apradiso.2009.12.033

Futamura, G., Kawabata, S., Nonoguchi, N., Hiramatsu, R., Toho, T., Tanaka, H., ... Miyatake, S. I. (2017). Evaluation of a novel sodium borocaptate-containing unnatural amino acid as a boron delivery agent for neutron capture therapy of the F98 rat glioma. Radiation Oncology, 12(1), 1-11. https://doi.org/10.1186/s13014-017-0765-4

Otersen, B., Haritz, D., Grochulla, F., Bergmann, M., Sierralta, W., \& Gabel, D. (1997). Binding and distribution of Na2B12H11SH on cellular and subcellular level in tumor tissue of glioma patients in boron neutron capture therapy. Journal of Neuro-Oncology, 33(1-2), 131-139.

R.F., B., M.G.H., V., O.K., H., W.S., K. I. I. I., K.J., R., P.J., B., ... S., K. (2012). Current status of boron neutron capture therapy of high grade gliomas and recurrent head and neck cancer. Radiation Oncology, 7(1), 1-21. https://doi.org/10.1186/1748-717X-7-146

Luderer, M. J., De La Puente, P., \& Azab, A. K. (2015). Advancements in Tumor Targeting Strategies for Boron Neutron Capture Therapy. Pharmaceutical Research, 32(9), 2824-2836. https://doi.org/10.1007/s11095-015-1718-y

Barth, R. F. (2015). From the laboratory to the clinic: How translational studies in animals have lead to clinical advances in boron neutron capture therapy. Applied Radiation and Isotopes, 106, 22-28. https://doi.org/10.1016/j.apradiso.2015.06.016

Hawthorne, M. F., \& Lee, M. W. (2003). A critical assessment of boron target compounds for boron neutron capture therapy. Journal of Neuro-Oncology, 62(1-2), 33-45. https://doi.org/10.1023/A:1023253309343

Coderre, J. A., Ph, D., Turcotte, J. C., Riley, K. J., Ph, D., Binns, P. J., ... Ph, D. (2003). Boron Neutron Capture Therapy: Cellular Targeting of High Linear Energy Transfer Radiation. 2(5).

https://doi.org/10.1177/153303460300200502

Bhupathiraju, N. V. S. D. K., \& Grac, M. (2013). Synthesis of Carborane-Containing Porphyrin Derivatives for the Boron Neutron Capture Therapy of Tumors. https://doi.org/10.1007/7081

Barth, R. F., Yang, W., Al-madhoun, A. S., Johnsamuel, J., Byun, Y., Chandra, S., ... Eriksson, S. (2004). Boron-Containing Nucleosides as Potential Delivery Agents for Neutron Capture Therapy of Brain Tumors. 6287-6295.

Barth, R. F., Yang, W., Nakkula, R. J., Byun, Y., Tjarks, W., Chu, L., ... Riley, K. J. (2015). Evaluation of TK1 targeting carboranyl thymidine analogs as potential delivery agents for neutron capture therapy of brain tumors. Applied Radiation and Isotopes, 1-5. https://doi.org/10.1016/j.apradiso.2015.06.031

Khalil, A., Ali, T., \& Tjarks, W. (n.d.). N3substituted thymidine bioconjugates for cancer therapy and imaging. 677-692.

Yang, W., Barth, R. F., Wu, G., Tjarks, W., Binns, P., \& Riley, K. (2009). Boron neutron capture therapy of EGFR or EGFRvIII positive gliomas using either boronated monoclonal antibodies 
or epidermal growth factor as molecular targeting agents. Applied Radiation and Isotopes, $\quad 67(7-8 \quad$ SUPPL.), 328-331. https://doi.org/10.1016/j.apradiso.2009.03.030

Wu, G., Yang, W., Barth, R. F., Kawabata, S., Swindall, M., Bandyopadhyaya, A. K., ... Fenstermaker, R. A. (2007). Molecular targeting and treatment of an epidermal growth factor receptor-positive glioma using boronated cetuximab. Clinical Cancer Research, 13(4), 1260-1268. $\quad$ https://doi.org/10.1158/10780432.CCR-06-2399

Azab, A. K., Srebnik, M., Doviner, V., \& Rubinstein, A. (2005). Targeting normal and neoplastic tissues in the rat jejunum and colon with boronated, cationic acrylamide copolymers. Journal of Controlled Release, 106(1-2), $14-25$. https://doi.org/10.1016/j.jconrel.2005.03.015

Maitz, C. A., Khan, A. A., Kueffer, P. J., Brockman, J. D., Dixson, J., Jalisatgi, S. S., ... Hawthorne, M. F. (2017). Validation and Comparison of the Therapeutic Efficacy of Boron Neutron Capture Therapy Mediated By Boron-Rich Liposomes in Multiple Murine Tumor Models. Translational Oncology, 10(4), 686-692. https://doi.org/10.1016/j.tranon.2017.05.003

Altieri, S., Balzi, M., Bortolussi, S., Bruschi, P., Ciani, L., Clerici, A. M., ... Ristori, S. (2009). Carborane derivatives loaded into liposomes as efficient delivery systems for boron neutron capture therapy. Journal of Medicinal Chemistry, 52(23), 7829-7835. https://doi.org/10.1021/jm900763b

Kawabata, S., Miyatake, S. I., Nonoguchi, N., Hiramatsu, R., Iida, K., Miyata, S., ... Ono, K. (2009). Survival benefit from boron neutron capture therapy for the newly diagnosed glioblastoma patients. Applied Radiation and Isotopes, $\quad 67(7-8 \quad$ SUPPL.), 15-18. https://doi.org/10.1016/j.apradiso.2009.03.015

Achilli, C., Grandi, S., Ciana, A., Guidetti, G. F., Malara, A., Abbonante, V., ... Minetti, G. (2014). Biocompatibility of functionalized boron phosphate (BPO 4 ) nanoparticles for boron neutron capture therapy (BNCT) application. Nanomedicine: Nanotechnology, Biology, and Medicine, 10(3), 589-597. https://doi.org/10.1016/j.nano.2013.10.003

Noguchi, H., Matsushita, M., Kobayashi, N., Levy, M. F., \& Matsumoto, S. (2010). Recent advances in protein transduction technology. Cell Transplantation, 19(6-7), 649-654. https://doi.org/10.3727/096368910X508744

Michiue, H., Sakurai, Y., Kondo, N., Kitamatsu, M., Bin, F., Nakajima, K., ... Matsui, H. (2014).
The acceleration of boron neutron capture therapy using multi-linked mercaptoundecahydrododecaborate (BSH) fused cell-penetrating peptide. Biomaterials, $35(10)$, 3396-3405. https://doi.org/10.1016/j.biomaterials.2013.12. $\underline{055}$

Meiyanto, E. (2014). Pengembangan boron carrying pharmaceuticals untuk mendukung terapi kanker berbasis bnct. 10-11.

Poedjomartono, B., Afkari, H., Meiyanto, E., Bangun, A. A., \& Sardjono, Y. (2019). Boron Neutron Capture Therapy for Cancer: Future Prospects in Indonesia. ASEAN Journal on Science and Technology for Development, 35(3), 199-201. https://doi.org/10.29037/ajstd.510

Qodria, L., Hairunisa, I., Utomo, R. Y., Hermawan, A., \& Meiyanto, E. (2019). Anti-metastatic Activity of Curcumin Analog Pentagamaboronon-0-Sorbitol Against HER2overexpressed MCF-7 Breast Cancer Cells. Indonesian Journal of Cancer Chemoprevention, $\quad 9(3), \quad 118$. https://doi.org/10.14499/indonesianjcanchemo prev9iss 3 pp 118-125 